\title{
AMERICAN INDIAN WOMEN OF THE PLAINS AND NORTHERN WOODLANDS*
}

Annette Kuhlmann

The University of Kansas

Mid-American Review of Sociology, 1992, Vol XVI, No. 1:1-28

This paper provides a descriptive introduction to the sociological study of contemporary American Indian women. An historical overview points to the traditional diversity of women's roles within and among cultures. It is argued that aspects of the diverse traditional roles, especially those as members of kin networks, continue to be important to American Indian women whose contemporary social and economic situation is explored through a critical analysis of 1980 Census data. These data are related to the lives and problems of contemporary American Indian women through an ethnographic discussion of Kickapoo women.

American Indians occupy little space and are given little significance in introductory sociology textbooks. A survey of current textbooks, which range in length between 600 and 800 pages, shows that discussion of American Indians is limited to 1 to 3 pages (Eitzen 1988; Eitzen and Zinn 1989; Farley 1990; Giddens 1991; Inciardi and Rothman 1990; Kammeyer, Ritzer, and Yetman 1990; Kerbo 1989; Vander Zanden 1990, Wallace and Wallace 1989). Typically, these texts discuss the European dispossession of American Indians, especially during the last century, and they mention American Indian political activism during the 1970s. This discussion is then followed by a short paragraph of quantitative data documenting American Indian poverty, health problems, high rates of alcoholism, and high birth rates. Only two, Kammeyer et. al. (1990) and Vander Zanden (1990) explore the continued exploitation of natural resources on Indian lands and violation of their treaty rights as some of reasons for their poverty and political resurgence. Kammeyer et. al. (1990) is the only text that even mentions the continued viability of Indian ways of hife and resistance to assimilation.

Despite the popular perception of American Indians as a distinct ethnic group, they represent a widely heterogeneous population with distinctly different traditions, modes of incorporation into the capitalist economy, and contemporary life styles. At the time of first contact with Europeans they consisted of at least 300 separate cultures and 200 distinct languages. These cultures included

* I would like to thank Dan Wildcat, Norman Yetman, and Akira Yamamoto for their helpful suggestions. 
theocracies and democracies, hereditary chiefdoms and matrilineages. The people lived in large urban areas, agricultural villages, or small mobile hunting bands. The different groups formed alliances with each other, traded, or fought each other in war (Dorris 1981; Cornell 1989).

The quantitative data in these textbooks veil this diversity and seldom reveal how the socio-economic conditions effect the lives of actual people, i.e. how they cope under poverty, biculturalism, and discrimination. Above all, however, these materials ignore the specific historical experiences and survival skills of American Indian women. As providers, caretakers, and craft people, women have always filled distinct roles and have been central to the survival of their communities, often possessing significant power and influence in the political decision making process. As mothers, wives, and professionals, a majority of them continue this tradition while living also in a post-industrial society. Yet their ways of adapting and surviving are far from uniform and vary greatly, depending on cultural background, opportunity, and individual history and disposition.

The neglect of these distinct and varied experiences of Indian women has a long history. Fur traders and missionaries as well as early anthropologists imposed the biases of their time and culture in their ethnographic writings and either ignored women in the cultures they described or depicted them as "beasts of burden" or "menial slaves" (Weist 1983; Kehoe 1983). Another classical stereotype of Indian women is that of the "Pocahontas Perplex" (Green 1975), where Indian women are described as beautiful maidens who lead white men through the dangers of the unexplored North American continent and protect them from lurking hostile savages. Today, popular picture books on American Indians depict only chiefs and warriors. The popular movie industry does not totally omit Indian women but relegates them to minor side roles, providing the background for male dialogue and action (Albers 1983). The recent, acclaimed movie Dances With Wolves is a case in point. The only female role of any importance is that of a white woman who had been captured by the Lakota in her youth.

During the 1970s and early 1980s a great volume of literature appeared on gender in third world societies (Etienne and Leacock 1980; Friedl 1975; MacCormack and Strathern 1980; Ortner and Whitehead 1984; Reiter 1975; Sanday 1981; Tiffany 1979). Yet the literature on American Indian women has been focused to large extent on autobiographical accounts (Hungry Wolf 1980; Linderman 1972; Lurie 1961; Udall 1969). Some other works describe the role of women in individual tribes in the last century (Buffalohead 1983; Grinnell 1972; Landes 1971; Niethammer 1977; Underhill 1979; Weltfish 1965). In contrast to these traditional anthropological approaches, several recently published studies take a critical approach and focus on the diversity of women's roles and the impact of colonialization on their positions (Albers 1983b; DeMallie 1983; Klein 1983; Medicine 1980, 1983; Deloria 1944; Powers 1986; Spector 1983). However, only a few works address the contemporary situation of American Indian women, the diversity of their life situations, their own
American Indian Women

perceptions of their problems and needs, and the different approaches they employ to integrate their bicultural contexts and cope with discrimination poverty, and often child care as single women (Albers 1983; Allen 1986; Guillemin 1975; Lamphere 1989; McElroy 1989; Medicine 1980; Whitehead 1980). More recently, fiction and poetry written by American Indians and especially American Indian women, for instance Silko (1977), Bataille (1984) Harjo (1982), Topahanso (1982), Erdrich ( 1985), or Gunn Allen (1986) portray the great diversity of their lives and emphasizes their efforts to recover their the great diversity of their lives and emphasizes their efforts to recover their traditional, especially spiritual, roles and their struggles to survive in the dominant Euro-American culture. Paula Gunn Allen in particular interweaves fiction, poetry, literary criticism, traditional story telling, and sociological research to discuss critically various dimensions of American Indian women's lives. She concludes that traditional Indian cultures were predominantly gynocratic and early Europeans were threatened by peoples who allowed women powerful positions in every aspects of society. Their fear of gynocracy thus contributed to the physical and cultural genocide of American Indian tribes.

It exceeds the scope of this paper to fully address these diversities in their various dimensions. Instead, I will discuss some of the roles and status variations Indian women have occupied in the past and, by analyzing data from the 1980 Census and from an ethnographic study of the Kickapoo of Oklahoma, examine the situation of American Indian women today.

\section{WOMEN'S ROLES IN HISTORICAL AMERICAN INDIAN CULTURES}

The situation of American Indian women cannot be understood in isolation they are integral members of their communities and traditions. Their lives are shaped by the roles their cultures conferred on them as well as the problems their communities have to face. Consequently, the roles of the women are defined in a variety of ways and they have performed an extraordinary diversity of economic, social, political, and spiritual roles. For instance, women in the Iroquois league have traditionally held strong and influential positions in their tribes. Although the chiefs were male, they were elected or recalled by the women; especially the powerful councit of clan mothers, who also owned the council's symbols. The division of labor was strict: the males hunted, fished, conducted trade and warfare, while the women worked in horticulture and gathering, i.e. provided the constant, reliable food sources. The women owned the products of their labor and could dispose of them as they wished. They could, for instance, stall a warfare party by withholding the necessary food provisions. In contrast to the men, the women worked in groups and their ties with each other, particularly within the clan, were so important that they outweighed the marriage relationships (Schumacher 1972).

Among the Pawnee, Mandan, Hidatsa, and Arikara, horticulturalists on the upper Missouri, women had similar roles and powers. The focus of tribal culture and activities was at least as much on the requirements of planting and harvesting, dominated by women, as on hunting and warfare. They lived in 
predominantly sedentary, economically autonomous, villages where women produced ample food surplus. They not only owned the products of their labor but also the meat and hides of the animals that the men had hunted. They freely traded these as well as their own products with other tribes and also the American Fur Company (Weist 1983). Descent was traced through the female line, i.e. membership in tribal divisions was determined by female ancestry. Matrilineal descent and emphasis on women's economic contributions gave them a strong voice in the political affairs of the community (Holder 1970; Weltfish 1965).

Apache culture emphasized war and raiding, but nonetheless women had a strong position, and few roles in that culture were closed to them. When an Apache woman married, her new husband became part of her family. Gathering food was women's responsibility and, since the tribal economy was largely based on her contributions, her status was high. Men were expected to hunt and raid to contribute to the tribal economy, but women could and did join them if they wished to do so. Apache women could attend all ceremonies and were able to obtain supernatural powers to the same extent as men. The tribe's oral traditions remember many successful women warriors and shamans (Buchanan 1972).

Among the Sioux or Lakota, as among other Plains cultures, life was organized around the hunt and warfare, activities conducted by males, who also controlled the tribal council and the religious ceremonies. Powers (1986) argues that polygamy was rare while Medicine (1980) reports that it was frequent. In any case, divorce could be initiated by either men or women. Men did so in a public ceremony while women could do so by placing their husbands' belongings outside the tipi home which was owned by her 1 . Kehoe (1983) describes the same kind of female initiated divorce among the Blackfeet; this right of women was feared in the tribe.

As already mentioned with respect to the Iroquois, most of the tasks performed by women were not done alone; women usually worked in groups, organized frequently along clan lines. Among the Lakota these groups were the tiospaye, the extended kin groups (Medicine 1980). Spector (1983) mentions women's work groups for the Hidatsa. As I will discuss more fully later, Kickapoo women today continue to work in groups to perform traditional tasks suct ås shelling and drying cort of weaving mats for wicki-up homes. In this manner work and socializing are not different activities, which makes for more efficient as well as more enjoyable labor.

18th and 19th century observers of the Plains tribes described the women as dominated by men and as "beasts of burden" (Weist 1983), yet these descriptions were more revealing of the observers' outlooks on women than their understanding of the complexities of the American Indian cultures' gendersystems 2 . When examined cross-culturally, some work tasks, such as gathering, tanning hides, and maintaining the home, seem to have been performed mostly by women yet the particular division of labor varied greatly between cultures. Early anthropologists simply assumed the division of labor to be the same as in Europe and did not research the issue carefully. Among the Pawnee, for instance, only women carved wooden food bowels while among the Omaha and Kickapoo this task was reserved for males. By contrast, among the Cheyenne, Blackfeet, and Hidatsa, this work was not restricted to either gender (Schneider 1983). Today, Kickapoo women prepare meals on an everyday basis while men cooked ceremonial meals (Kuhlmann 1989). Among the Ojibway, men and women often used their distinct skills and work skill to complete a task together. For example, in canoe building men created the birch bark frame while women sewed bark to the frame and made it watertight (Buffalohead 1983).

Among the Lakota and Kickapoo, as among many other tribes, women performed much of the labor that sustained the camp. They tanned hides, gathered food, cared for the children, and maintained the household and home such as tipi or wicki-up; sometimes men helped with the hard labor. Deloria (1944, cited in DeMallie 1983) feels that Lakota men were exempt from much of the work because they had to be ready at any time to defend their families and communities. The household was the women's sphere and under their control, i.e. women owned the wicki-ups, tipis or earth lodges and could divorce a man by disposing of his belongings. Their rights and responsibilities gave the women a clear sense of identity and place in the community and, through industry and generosity, they could gain great respect in the community (DeMallie 1983; Kehoe 1983). Some of their tasks, such as mat weaving, bead work, and quilt making, were refined to art forms by some women and could lead to high statuses in their communities. Among the Lakota and Cheyenne, quilting women formed a secret society with special spiritual tasks (Albers and Medicine 1983; Grinell 1972).

This great diversity of roles available to American Indian women affected their power within their respective cultures. Female fertility and power were symbolically linked among many, if not all tribes. Among the Lakota, for instance, women were attributed special sexual powers through which they could endanger men and male warfare and ceremonial objects. At the same time an ideal was placed on female purity. Young girls were closely watched and interpersonal relationships between the sexes were carefully limited. Among other groups, such as the Mandan and Comanche, in contrast, women were not under such constraints (Medicine 1980; Holder-1970). Women faithful to-2heirhusbands were honored among the Lakota, Arikara, Crow, and Blackfeet in special ceremonial roles such as the Sun Dance woman and in the "Bite the Knife" ceremony (Weist 1983). However, women also had other options as in the respected roles of 'witkowin' (Double Face Woman) among the Lakota or 'matsaps' (Crazy Woman) among the Blackfeet. Among the Piegan and the Blackfeet women who felt independent could become Ninawaki' or the 'manly hearted woman' which allowed them to attain wealth in a similar fashion as males. In many cultures including the Apache, Kutenai, Ojibwa, Cherokee, Gros Ventre, Mandan, Pawnee, Eastern Dakotas, Blackfeet, Cheyenne, and the Crow, women became warriors, on a temporary or permanent basis, when their traditional female roles became too restrictive. Among the Cheyenne and Apache these women had their own societies and were highly respected in their 
communities for their bravery and skill (Medicine 1983; Holder 1970; Buchanan 1986; Grinell 1972).

In most Indian cultures, like the Lakota, the division of labor was strict but was felt by some to be organized to provide a sense of complementarity and interdependence between the sexes (DeMallie 1983; Powers 1986). It contributed interdependence between's sense of security, expertise, and accomplishment in their to the women's sense of security, expertise, and accomplishe treaining and resourcefulness (Whiteman 1980). The high esteem in which women were held is expressed by one of DeMallie's resource persons "Symbolicly, the Lakotas believed their society to be no stronger than their women" (DeMallie 1983, p. 261). Kehoe (1983, p. 69) describes a similarly strong position of the Blackfeet women:

Their families and tipis were constant mute witnesses to women's capabilities whereas men had to recount again and again their ephemeral deeds in war lest they may be forgotten.

Grinell discusses the same attitude towards women among the Cheyenne when he writes:

Women are the rulers of the camp. They act as a spur to the men, if they are slow in performing their duties. They are far more conservative than men, often hold them back from hasty, ill-advised action. If the sentiment of the women of the camp clearly points to a certain course as desirable, the men are quite sure to act as the women wish (Grinnell 1972, pp. 128-129).

Another example of the respect for women is the role of women in religious life. White Buffalo Woman brought the pipe to the Lakota, which is the central means by which they communicate with the spirit world. Among the Blackfeet, women were the custodians of the sacred medicine bundles (Amott 1991). Among the Pawnee, Mandan, and Hidatsa a neophyte who wanted to learn special medicine skills or care for bundles was required to be accompanied by his wife. In fact, the medicine bundles themselves were perceived as female, and female deities; such as the corn mother, were central in their religious system (Holder 1970). As discussed above, among the Iroquois, women occupied a strong social position, yet their status was not reflected in the Iroquois religion through, for instance, a centrally important female deity (Schumacher 1972).

These examples show not only the diversity of women's spheres among traditional American Indian cultures but also the variety of roles available to women within any one group. The complexity of the gender role system does not allow for simple labels such as 'male dominance', 'patriarchy' or 'matriarchy'; instead we have to be open to kinds of power and ways of exercising influence that are different from those familiar to us, especially under conditions in which the domination is exerted by a force outside the community.

\section{INDIAN WOMEN, COLONIALIZATION, AND FEDERAL INDIAN POLICIES}

The foregoing descriptions attempt to highlight the diversities of Indian women's roles before confinement on reservations. However, cultures, and, thus also women's roles, are not static but flexible, changing according to needs, historical opportunities, and inclinations of individual peopie. Contact with Europeans implied profound changes in many aspects of American Indian cultures. European contact and the ensuing incorporation of American Indians into the Euro-American capitalist system can be divided into distinct stages which will only be summarized here 3 .

The initial contact period included the introduction of the horse, the fur. trade, and the outbreak of epidemics. The second stage encompassed the dislocation of the tribal groups from their home territories, deterioration of the indigenous economy, and confinement on reservations as domestic dependent nations. The third stage involved forced acculturation through individual allotment of tribal land and formal education. The next stage, beginning in the 1950s, involved efforts of the federal government to terminate unilaterally its treaty obligations to the tribes. To this end the government established programs to relocate the Indian population to urban areas and to integrate them into the American labor market. In the 1960s, the treat of termination, the Civil Rights Movement, and social unrest in the country at large, as well as a need for the natural resources on Indian reservations led to another stage. This period was characterized by increased ethnic pride and political activism that culminated in the American Indian Movement (AIM) and the American Indian SelfDetermination and Education Act of 1975 . The nature of Indian-White relations in the 1980s and 1990s can not yet be clearly discerned but cuts of federal funds for Indian communities (Stuart 1990) and emphases on litigation in the regulation of Indian affairs appear as important elements.

Europeans affected Indian cultures long before military conflicts between the two parties began, in some incidents even before any direct contact occurred. The horse, which was introduced to North America via the Spaniards, reached the norttiem Plains in the earrly 18 th cếntury and altered these tribes' life styles profoundly. For instance, raiding activities developed to obtain horses and, as a consequence, migrations could cover much larger distances (Buchanan 1983; Holder 1974). Until the arrival of the horse, the buffalo hunt had been conducted predominantly through cliff drives. This method required collective involvement of every group member and the product of the hunt was distributed equally in the community. The horse, however, was owned individually and changed the hunt to a chase of the prey. The women followed the men to skin and cut the kill of the males of their households. The horse thus individualized the hunt, emphasizing personal property instead of communal distribution (Klein 1983). In the process the status of male activities increased and the role of women became more limited. 
The advent of the fur trade not only brought a stronger emphasis on male hunting activities. Since it was introduced at about the same time as the horse, hunting became a much more effective enterprise and greatly increased the women's work load such as tanning. The resulting change in the tribal economies may have reduced the status of women in some communities (Klein 1983). However, in other societies, where the women actively participated in the fur trade, the opposite occurred (Buffalohead 1983).

Contact with Europeans led to devastating outbreaks of epidemics among the American Indian population across the whole continent (Thomton 1987). As a result this population was so dramatically reduced that most social institutions were affected (Ronda 1984, Martin 1978). Yet no data are available to determine how these population losses effected the roles and statuses of women.

The greater emphasis on hunting resulting from the fur trade implied an increase in migration, which in turn led to a neglect of the horticultural activities of women (White 1983). It is likely that this trend reduced the status of women in some societies. Although this development meant a greater dependency on white traders, it was not until the forced relocation of many tribes to reservations that the cultures were profoundly disrupted. Under the artificial and confined environment of the reservations men and women had little power to effect their fates. Under these conditions the most obvious change was the disintegration of the male role of warrior and hunter (Powers 1986). The women's roles as gatherers, horticulturalists, traders, artists, medicine women, and, especially as wives, mothers, and caretakers were on the surface more continuous; but the profound changes and deprivations must have also affected them decply.

Medicine (1980, p. 149) addresses the lack of data on these issues:

But what of the roles of women in relationship to agents, to soldiers guarding the "hostiles," and to their general physical deprivation in societies whose livelihood and way of life had been destroyed along with the bison? We are very nearly bereft of data and statements which would clarify the transitional status of Indian women during this period. The strategies adopted for cultural survival and the means of transmitting these to daughters and nieces are valuable adaptive mechanisms which cannot

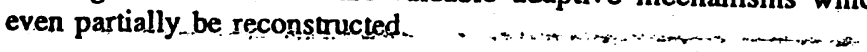

Women did, however, continue to maintain their own gardens, which often provided the only income independent of the federal Government (Albers 1983; Dillingham 1963). The reluctance of European-American males to interact professionally with native women throughout this period, as discussed, for instance, in Buffalohead (1983), must have severely curtailed the few business opportunities available to Indian women.

In the 1880 s the federal Government began a concerted effort to assimilate American Indians through a two-pronged approach: individual allotment of the communally held tribal land and formal education. Both had profound impacts on the situation of women, although data on the precise effects of these efforts
American Indian Women

are, again, sparse. Especially after settlement on reservations, the federal Govermment tried to deal with Indian housholds according to Euro-American standards and limited its interactions to males. It distributed annuities, for instance, only to male "heads of households". This trend was enforced in the Dawes Act of 1887, through which communally held land was divided into small parcels, some of which were alloted to individual male head of households who were expected to farm this land, traditionally the task of women. Women could only gain ownership of land through widowhood or divorce, and some of those who did were comparatively successful in their agricultural enterprises (Buffalohead 1983).

Through formal education Indian children were expected to learn the skills necessary to survive in and assimilate into the Euro-American society. Beginning in the 1880 s they were often forced to attend federal boarding schools and separated from their families and communities (Kuhlmann, forthcoming). Many of the girls especially responded with high levels of anxiety to the unfamiliar environment (Medicine 1980). The curricula were strictly gender segregated according to Euro-American standards. The girls learned domestic tasks such as cooking, cleaning, and sewing, while the boys were instructed in shop, trade, and farm skills (Szasz 1971). After returning to their respective communities some of the women integrated their new skills into the traditional culture as in the example of the starquilt and could, in this manner, enhance their position (Albers and Medicine 1983).

American Indians were not systematically introduced to the labor market until the Bureau of Indian Affairs (BIA) expanded in the 1930s under John Collier. But a significant number was not employed until the 1950 s when the federal Government established programs to provide job skills and to relocate Indians to urban areas (Jorgensen 1986). It is not clear to what an extent women participated in these programs, which were apparently geared predominantly towards male wage earners (Albers 1983b; Flynn 1989). In any event, few women adjusted to urban life, and a majority migrated between the reservation and the city bringing news about urban life to their communities.

The 1960s was a period of general social unrest in the US. The Civil Rights movement had sensitized the public to the plight of suơjugated ethnic minorities. The anti-war movement criticized the US imperialistic activities in and outside the country (for theories of internal colonialism see Blauner 1969). The grievances that existed on reservations and in urban Indian communities were a result of a history of colonialization, poverty, constant threat of termination, and discrimination. The dissatisfaction about Indian education in public or BIA schools coincided with other grievances, which included the abrogation of treaty rights and corruption in the BIA. The American Indian Movement (AIM) of the 1970 represented a protest against this repression and injustices. The activists mobilized to rectify these wrongs and to reestablish some control over their lives, particularly with respect to government, affirmation of the indigenous cultures, use of natural resources on the reservation, and education. Their concerns were acknowledged in the Indian Self- 
Determination and Education Assistance Act of 1975, in which Congress responded to Indian demands for increased power of tribal self-government (Jorgensen 1978, 1986; Josephy 1971, 1982; Matthiessen 1983; Nagel 1988, 1990).

Women were prominent participants in most AIM actions. They were occupiers of Alcatraz; they marched on Washington; and were also victims of the ensuing violence between AIM and the FBI on the reservations. They were instrumental in establishing survival schools where special curricula taught Indian children to feel confident about their heritage while they learned at the same time to survive in the Euro-American society. Indian women also formed AIM's sister organization, WARN (Women of All Red Nations) and initiated, for instance, the Black Hills Alliance, an organization dedicated to protect Dakota land claims to the Black Hills (Matthiessen 1983). Today Indian women continue to participate in, and often lead tribal and pan-Indian affairs. They are tribal chair persons, head organizations which work to obtain and facilitate federal monies for Indian organizations ${ }^{4}$, and continue to be dedicated activists (Silman 1987).

\section{THE 1980 US CENSUS}

According to the 1980 Census the American Indian population numbered 1,418195 people, half of whom ( 50.6 percent) were women. The picture this census presents of American women shows some aspects of a grim situation5.

Indian women have the highest fertility rate of all ethnic groups in nearly all cohorts. Among the 15 - 24 year olds Blacks have slightly more children per 1,000 women ( 530 vs 540 children), but the fertility rate is reversed for older women. When differentiating among the different groups of persons of Spanish origin, major variations appear. Puerto Rican women age $15-24$ years and Mexican women aged 25 - 44 years bear slightly more children than Indian women. Many of these children grow up in difficult socio-economic circumstances. 20.8 percent of all Indian households have annual incomes of less than $\$ 5000$ as compared to 25.5 percent of Black households, and 17.6 percent Hispanic and 11.4 percent white. 22.7 percent of all Indian families are headed by women with no husband present, a rate that is exceeded only by the percentage of single mother families among Blacks (37.2 percent) and is more than twice the rate of whites (10.6 percent). 52 percent of Indian single mothers households with children under the age of 18 years live below the poverty level, which is similar to the rate of Blacks ( 52.5 percent) and below the rate for people of Spanish origin (56.3 percent) ; 62.5 percent of these Indian families with children under the age of 18 live below 125 percent of the poverty level as compared to 38.8 percent of white families. The median income of Indian women (\$4937) was the lowest of all ethnic categories, except for Puerto Rican women (\$4247). Indian women with children fared somewhat better in comparison. Their median income of $\$ 6635$ was higher than those of Blacks,
Mexican and Puerto Rican women, but significantly lower than that of white (\$ 9367) and Asian (\$ 9464) women.

Again, these data veil the great differences among especially the reservation populations. Considering the income of all persons aged 16 years and older living on reservations, men's median income in 1979 was $\$ 4693$ and women's \$ 3171. Yet among the Laguna Pueblo, New Mexico the median income of males was $\$ 10712$ and that of women was $\$ 4325$. Similarly, on the Spokane reservation in Washington men had mean earnings of $\$ 10805$ and women $\$$ 4926. In contrast, on the Lac Courte Reservation in Wisconsin men earned \$ 3858 and women \$ 3757; on the Papago Reservation in Arizona men's median earnings were \$2564 and women's \$ 2528; on Standing Rock, South Dakota, men's median income was $\$ 2755$ and women's $\$ 2136$. It appears that the income of women, although also varied, does not differ as greatly across reservations as that of men. In a few communities, however, women's income exceeded that of men in 1979. Among the population of the Wood County section of the Winnebago Reservation in Wisconsin, women had a median income of $\$ 5606$ in contrast to $\$ 2408$ for men. On the Chehalis Reservation, Grays Harbor County, Washington women earned \$ 5132 while the median income for men was \$3722. Also, among the Havasupai in Arizona women's median income of $\$ 3479$ exceeded that of men $(\$ 2564)$.

Indians are often stereotyped as living predominantly on welfare. The census data do not bear this out. In 197917.3 percent of all Indian households lived with public assistance income as compared to 5,6 percent of white and 15.9 percent of Spanish origin, and 22.5 percent of Black households. The rate for people of Spanish origin is deceptive because of the diversity within that group. Mexicans have a significantly low rate ( 13.5 percent) than Indians, whereas Puerto Ricans' rate (31.4) is much higher, the rate of Cuban is the same as that of Indians overall. With respect to the reservation population, however, poverty status was determined for 44.8 percent of all households of this population and 41.5 percent received benefits in 1979 .

The extensive poverty among Indian families and, particularly, among Indian women can in part be related to their level of education. The census reports that 57.3 percent of all Indian males and 54.3 percent of all females graduate from high school. It also found that 24.5 percent of Indian males and 24.2 percent of Indian females have 8 years or less of education. .9 percent of Indian males and .6 percent of the females have a college degree. Yet these data are misleading because of the diversity of the Indian population in terms of urban - rural differences as well as variations between reservations. Considering all persons living on reservations, 16.2 percent have completed less than 5 ycars of schooling, 27.1 percent of the 16 to 19 year olds are not enrolled in school, and only 43.2 percent have graduated from high school. Unfortunately, these data do not distinguish according to gender. The rates for Indians on reservations vary greatly according to the various communities as some examples will show. Among the Hopi (Coconino County, Arizona) 33 percent of the population has less than 5 ycars of education, 11.9 percent of the 16 to 19 year olds are not 
enrolled in school, and 32.5 percent have graduated from high school. On the Miccosukee Reservation. Florida 60.2 percent have completed less than 5 years of schooling, 56.0 percent of the 16 to 19 year olds are not enrolled in school, and 19.4 percent of this population have graduated from high school. Among the Southern Paiute 35.7 percent have completed less than 5 years of schooling and 7.1 percent of have graduated from high school. No data were available for those enrolled in highschool in 1980. Among the Navajo 37.4 percent have completed less than 5 years of schooling, 24.3 percent of the 16 to 19 year olds are not enrolled in school, and 34.1 percent of this population have graduated from high school. In the Santa Clara Pueblo, New Mexico only 3.4 percent have completed less than 5 years of schooling, 6.3 percent of the 16 to 19 year olds are not enrolled in school, and 68.3 percent of this population have graduated from high school. These variations may be due to geographic location, nature of the community, and quality of the available education.

The nature of Indian women's work also contributes to their high level of poverty. According to the census, 47.7 percent of all Indian women over 10 years of age were in the labor force in 1980, but 11.9 percent of them were unemployed, the highest rate for all ethnic groups. The labor force status is only broken down for 1979 . During that year 28.3 percent of the Indian women respondents were unemployed for some time, 11 percent were without work for 15 weeks or more. Yet of those women who were employed, only 40.0 percent worked 50-52 weeks of that year and only 34.7 percent worked 35 hours or more a week. Both of these rates are the lowest for any race or gender category. In addition to their low rate of full employment Indian women work predominantly in low paying jobs. 38.5 percent worked in technical, sales and administrative support occupations, including clerical; the latter category alone accounts for 27.4 percent of all working Indian women. The service industries employ 25.3 percent. The census also reveals an unusually high number of Indian women in managerial and professional specialty occupations. With 18.1 percent Indian women excced women and men of all other racial groups, including Indian males, except for whites and Asians. One possible explanation is Aberle and Flynn's (1989) argument that women who have obtained some education can find, and prefer to work on their respective reservation. Men, in contrast, can find relatively well paying jobs outside the reservation that do not require as much education, for instance, in construction. Federal grants allocated to Indian tribes in the late 1970s provided new job opportunities on reservations, especially in administration and education, occupations which are typically women's work.

\section{Discussion}

With respect to the census data Snipp's (1986) warns: "user beware, demographic date are not always what they are alleged to be" (p. 248, emphasis his). This is certainly true for the American Indian population in general and Indian women in particular. The distortions of these data are manifold.
For example, the Oklahoma Kickapoo tribal members, discussed below, continually evade to be registration in the US census and their reluctance has historical origins. It is related to their historic strategy of passive resistance to avoid enforced culture change and to maintain their autonomy. In order for the federal government to impose allotment or formal education on Indian tribes, including the Kickapoo, it had to collect demographic data. So the Kickapoo learned to associate census taking with government actions detrimental to their interests. Therefore, especially the culturally conservative faction continues to resist such impositions by keeping their actual tribal population obscure. Moreover, the Kickapoo still employ the traditional method of determining tribal membership. It implies a kinship system according to the Omaha type, a naming ceremony, and placement in the tribal religious order, which differ from the government's definition of a minimum of one quarter blood descent. According to the Kickapoo's definition of tribal membership, some children are enrolled in other tribes. Furthermore, the Kickapoo community's membership is not stable. There are frequent and extended visits between the Kickapoo populations in Nacimiento, Mexico, Eagle Pass, Texas, and Oklahoma. Other tribal members work as migrant laborers and are therefore often absent for long periods of time (Kuhlmann 1989). Consequently, it has to be assumed that any census severely undercounts the Kickapoo in Oklahoma.

Deloria (1984), in contrast, argues that Indians are overcounted. Between 1970 and 1980 the American Indian population nearly doubled from 792,730 to 1,418195 (US Department of Labor 1983). This trend seemed to have continued since preliminary data from the 1990 census indicate a further increase of $\mathbf{3 8}$ percent, i.e., an American Indian population of about two million people (Johnson 1991). As Deloria (1984) noted, neither biological reproduction, nor the meager federal resources, nor increased opportunities of affirmative action can fully explain this population growth. Rather, he argues, the historically stigmatized view of Indians was replaced by a new image of Indians as political activists and spiritual and ecological leaders in the 1970s and has lent respectability and personal stability to an identification as American Indian. Since the Census does not require proof of ancestry, it is not possible to determine how many people with only a small percentage of Indian blood declared such an identity (Johnson 1991).

Snipp (1986) shows the extent of this complexity when he distinguishes between three kinds of Indian identity differentiated in the census: 1) those who declared their race and ethnic background as American Indian (less than 1 million), 2) those who report their race to be Indian but their ancestry as mixed (less than 300,000), and 3) those who identify themselves as non-Indian but have Indian ancestry (5.5 million). In 1980 nearly 7.5 million persons reported their race and/or ancestry to be Indian.

Only those persons who identified their race and ethnicity as American Indian are likely to practice elements of their traditional cultures, especially in terms of language use. Snipp also found significant socio-economic differences between the three groups. The first group as identified in 1) above, have slightly 
less education than the other two groups, 10.7 mean years of education versus 12.3 for group 2 and 11.5 years for group 3, respectively, and their households earn less money $(\$ 8,307$ compared with $\$ 10,680$ and $\$ 10,742$ respectively). These differences are even more pronounced with respect to the poverty status. 29 percent of American Indian households fall below the poverty level while only about half of this rate (15 percent) of the households of Americans with Indian descent fall into this category. The proportion of Indians with multiple ancestry is only slightly higher (17 percent). Similarly, only 44 percent of American Indian households have incomes that range twice as high as the poverty level while 63 percent of those Americans of Indian descent and 61 percent of those with multiple ancestry do.

Thus on one hand, the American Indian population increased according to the 1980 census due to among others, a larger number of people reporting their ethnic identity to be Indian. Yet on the other hand, traditional Kickapoo, and most likely traditional Indians of other tribes, have historically avoided to be enumerated by the census. According to Snipp poverty tends to be even more severe among the traditional tribal members than among those who are relatively acculturated. Consequently, the socio-economic characteristics depicted by the census may underrepresent the realities of poverty and undereducation among American Indians.

In some instances the census indicates the diversity among Indian women in the same or among different communities. The distribution of Indian women in pink collar as well as managerial positions was discussed above and points to tendencies of class segregation among them. The data for selected reservations show extensive differences among communities and even between counties within one tribal area. Unfortunately, these data do not distinguish between gender except for income. Here also the differences among communities and the variations between the income of men and women are significant. Other important areas of diversity are, however, not reflected in these data. As mentioned above, the role of women in traditional American Indian societies varied greatly, especially with respect to work, status and political influence. For many Indian women, the community, its values and traditions remain central parts of their lives (Powers 1986). Paula Gunn Allan (1986), for instance, discusses the extent to which the traditional spiritual life, a spiritual understanding of life, continues to be important to many Indian women. It provides meaning to their lives, guidance, and nurturance. The great variety of traditional cultures and forms of Indian incorporation into the broader society as well as the differences in opportunities open to Indian women today, necessarily lead to great diversities in their lives and in the manner in which they combine both cultures and survive under poverty. The census data thus only reveal the proverbial tip of the iceberg. In the following I will discuss data from my own field work among the Kickapoo of Oklahoma in 1986 and 1987 to relate some of the census data to the realities of the actual life situations of one group of American Indian women.

\section{GLIMPSES OF LIVES BEHIND THE NUMBERS: THE KICKAPOO OF OKLAHOMA}

The Kickapoo originated in the Wabash and Illinois river country and belong to the Algonquian linguistic family. Traditionally they lived predominantly as hunters and gatherers. After contact with Europeans and later Americans, the Kickapoo continued to use strategies such as migration, warfare, and cultural renewal through religious revitalization to protect their cultural and political independence.

In the 1830s a small section of the tribe settled permanently in Kansas. At about the same time, other bands accepted the Mexican Government's invitation to defend the latter country's national border in exchange for a land grant. A relatively small segment of the tribe still lives in Mexico, litule disturbed by any government agencies. Another small community is found in Eagle Pass, Texas, at the border with Mexico. The Kickapoo tribal group now living in Oklahoma migrated in Mexico, Texas and Oklahoma until the very end of the 19th century when they settled permanently in their present location. The present study is concemed only with the Oklahoma group.

Today the Kickapoo tribal members in Oklahoma live in relatively isolated communities about 35 miles east of Oklahoma City. IKWAI F.O.R.C.E., the Foundation for the Organization of Resources for Cultural Equity, an organization that provides bicultural educational materials and services to the Kickapoo, estimates their population to be about 1800 tribal members 6 . They have retained their tribal heritage to a large extent. A large majority speak their tribal language, observe their religious ceremonies, and maintain some of their traditional homes, the wicki-ups. While the Kickapoo continue in many ways to pursue their traditional ways of life, many find it difficult to function in the Euro-American society. Their situation is characterized by a dearth of political and economic resources, and the combined stresses of poverty, forced acculturation, and discrimination led to such symptoms as high rates of substance abuse, deterioration of family units, unemployment, health problems, and low educational achievements and low self-esteem among the young. Yet the Kićkapoo's still viable traditional culture continues to be a positive and constructive force in their community.

Mothers

As the census data have indicated, many American Indian women have children at an early age. This holds also true for Kickapoo women; a majority of the women in their early thirties that I encountered in this community were already grandmothers. But instead of viewing teenage pregnancies as simply another symptom of poverty, they reveal a different understanding of parenthood. Kickapoo youths are considered adult at the age of about 14 years and are given the rights and responsibilities conferred by this status in the community. Childbearing is one of the ways in which the young adults respond to expectations of the community and confirm their new status. 
Marriage among the Kickapoo is still defined in traditional terms, though no formal gift exchange takes place. A couple is considered to be married when other tribal members "see them around together." In fact, this quote is the literal translation of iichehaka (spouse). Kickapoo marriage is usually accepted by the American authorities as common law marriage. Yet mate selection is difficult for Kickapoo women. The traditional occupation of Kickapoo males centered on warfare, hunting, and ceremonial activities. In Oklahoma the traditional role of males as provider and protector has become obsolete, because legal restrictions prevent them from hunting. Males cannot protect their families and tribe from an intruding bureaucracy, poverty, and discrimination. Instead, they often escape through residence in Mexico among their relatives in Nacimiento, migrant work, or substance abuse. Without a meaningful traditional and contemporary role, the Kickapoo men become inadequate fathers and spouses. A woman told me: "They are supposed to take care of the woman and the children, but don't." . The only important function still left to Kickapoo males in Oklahoma is their role in the religious realm. Dillingham attributes the strong emphasis on this secret role to the loss of the men's functions and importance in the secular realm (1963, p. 271).

As I have discussed elsewhere (Kuhlmann 1989), the Kickapoo have used migration, as well as warfare and cultural renewal through religious revitalization, as a strategy to avoid conflict and pressures to acculturate. Kickapoo men especially still employ this strategy in an adapted form. Instead of the past migrations of Kickapoo bands throughout the Plains, the tribal members, especially the men, travel now individually or with their kin as often as possible. Their favorite destination is Nacimiento, Mexico were their relatives reside, relatively undisturbed by the Mexican government. Kickapoo men prefer to live in the Mexican Kickapoo community because their traditional role there is more coherent and meaningful in this more traditional environment. For example, they still hunt in the traditional way.

Another form of adaptation of this traditional strategy is migratory labor. The mostly male workers usually leave the communities in Oklahoma or Mexico after the spring ceremonies, which open the Kickapoo year, and return for the harvest festivals. Throughout the intervening months they follow the harvest along the west coast. During this time they live in near isolation from the Euro-American society interacting primarily with other tribal members and secondarily with Indians from other tribes and Mexicans. Since it is not necessary for them to be proficient in English or have any formal education in this occupation, many tribal members feel that it enables them to live their traditional, non-sedentary life-style more than any other occupation. Thus this work contributes to the maintenance of their culture.

In contrast to Kickapoo men, a majority of the women live relatively permanent in Oklahoma since in the US they can receive welfare monies, have a greater chances of finding employment, and their children can obtain some of the education necessary to function in the dominant society. High incarceration and death rates due to substance abuse have reduced the small number of available
Kickapoo males. Kickapoo women also often do not want to live with an alcoholic spouse. In this tribe, as among the Navajo (Levy et. al. 1989), exogamous clan rules further limit the pool of marriageable men. Consequently, many Kickapoo women marry outside the tribe, particularly Mexican men. This is a notable change because as late as the 1950s the Kickapoo were still considered a tribe of full bloods (Silverberg 1957; Wallace 1969). Kickapoo women keep their tribal membership when they marry Mexican men, but since the Kickapoo are patrilineal, the children from these unions are not considered tribal members in the community which is great burden on these women.

The number of single Kickapoo women was estimated by IKWAI to be about 94.2 percent while the Kickapoo Community Health Representative mentioned about 75 percent in the age group 16-30. In the older age group the ratio between single and married mothers is reversed; however, the majority of married women live with Mexican husbands. These high rates of Kickapoo households headed by single women have to be understood in the light of the frequent and extended absences of their mates due to residence in Mexico and migrant work as well as the pervasive substance abuse. The pressures of poverty, discrimination, and multiculturalism further contributc to the frequent dissolution of marriages, and many Kickapoo women live in serial monogamous relationships. Guillemin (1975) reports the same traits for the urban Micmacs in Boston and Aberle and Flynn (1989) for the Navajo.

\section{Work}

The urban - rural distinction is not so pronounced for the Kickapoo as it is for most other tribes because they live within commuting distance of a metropolitan area, about 35 miles east of Oklahoma City; some tribal members also live in other urban centers. In any case, their households are closely interconnected through frequent visiting, mutual help networks, wage transfers to the residents in the rural tribal area, and the frequent care of children of urban and/or wage eaming mothers by relatives. This holds true not only for the Kickapoo but also for other tribal communities (Guillemin 1975; Lamphere 1989). Aberle and Flynn (1989) go as far as saying that "Today and in the future, the rural and non-rural sectors of Navajo society must be understood as a whole and not as separate entities" (p. 427).

Some Kickapoo women work in the tribal head start program, others in the Kickapoo Tribal Clinic, or at IKWAI. Several of the women who live in the urban area closeby are employed at Tinker Airforce Base. Many women accompany their husbands for the seasonal migrant labor while also earning an income. Several women continue to work exclusively in the Kickapoo community and pursue traditional tasks such as horticulture and gathering, including "hunting wild potatoes", i.e. Jerusalem artichokes. They are involved in traditional crafts, especially weaving baskets and mats as well as beading and sewing, maintenance of wicki-ups, and caring for their families. Some Kickapoo women still maintain "wicki-ups", the traditional Kickapoo homes that the women own. These houses, each set of which includes a summer and a 
winter home, are important for the community as a whole, not just for the individual family since they provide links with their past and their traditions. They are also central to the observation of ceremonies and thus keep the residents in close contact with their spiritual lives (Ketcheshawno 1984). Especially the older women often take care of a number of youngsters who are grandchildren to them "Indian way." A majority of Kickapoo women are involved in these activities on a part time basis, when the need arises. This means their work burden is threefold: they are employed in a wage earning job, they care for their children, and they perform traditional female work tasks. All the Kickapoo women I talked to maintained their own bank accounts while being married to preserve some economic security and independence.

\section{Education}

Since the Kickapoo's first exposure to the Federal Government's efforts to enroll their children in formal education, the tribal members resisted. They were aware of the underlying intentions and inherent dangers of Euro-American schooling to acculturate the young into the dominant society and alienate them from the tribe. Their resistance even became violent in 1895 when they occupied in protest a section of their land allocated for a school (Dillingham 1963, p. 61). The contemporary Kickapoo feel ambivalent about the education. They continue to share in the above-mentioned attitudes and resent schooling for its dangers to their cultural identity. At the same time, however, the tribal members are aware that they need technical skills and proficiency in the English language to function in both societies, to protect the tribe's interests, and to achieve at least some degree of economic and political independence. This dilemma is one of the core problems of the contemporary Kickapoo as it is closely related to their increasing social dislocation.

Today, the formal education of Kickapoo children enrolled in the area's public school system is characterized by low educational achievement, grade retention and a high drop-out rate. The length of time Kickapoo adults have been enrolled in formal education averages 8 years (Bob Ward, director of Central Tribes of the Shawnee Area, personal communication; IKWAI's estimate in the 1986 grant application under Title IV). The undereducation not only reduces the Kickapoo's employment opportunities, but is one of the reasons for their difficulties in coping with the dominant Euro-American society.

The language barrier is the main impediment to the formal education of Kickapoo people. Many adults speak Kickapoo, and maybe Spanish and/or English, or are at least proficient to some degree in the latter two. In a majority of Kickapoo homes, however, the tribal language is spoken exclusively. Consequently, the majority of children enter kindergarten as non-English speakers. According to the resource persons I talked to, it takes children two to three years to learn the foreign language. In fact, many of the adults learned English from their children. The experience of being confronted with a new language in a new environment and different modes of behavior at such an early age was and is very difficult for many. One resource person told me "when I came to school and could not speak a word of English I thought my mother wanted to punish me. Until then, I did not know that there was a United States out there". This quote illustrates the shock many children experience when they are suddenly confronted with a different society from which their community lives are detached or isolated.

In addition to the unfamiliar social, linguistic and physical environment, the children have to cope with new learning styles. The traditional Kickapoo ways of learning and teaching are characterized by a caring, calm, one-to-one relationship. The child is taught when it is considered mature enough, when it shows an interest in the task and when the appropriate situation arises. The learning method is wholistic and is based on observation and imitation rather than on formal instruction. The child learns mainly through a tactile method of physically handling the learning object instead of through abstract instruction. Abstract concepts are taught through story-telling. The learning takes place in the familiar home environment instead of a social and physical setting formally seperated from the community and its everyday life activities. In the past small children and girls were predominantly taught by women, their biological mothers and their aunts and grandmothers, titles which refer to any Kickapoo woman. Today the absence of Kickapoo men due to migratory labor, substance abuse, or residence in Mexico further reinforces this trend, thus women are the predominant transmitters of Kickapoo culture. These cultural and linguistic differences put Kickapoo speaking children at a disadvantage in school and is to a large extent responsible for the grade retention and high drop-out rate.

\section{Households}

However, many of the wage earning jobs are, however, not permanent, and IKWAI estimates that about 98.6 percent of the tribal households have a standard of living below the governmentally defined poverty level. The Kickapoo, as well as other Indian households, are not the stable nuclear family predominant in the Euro-American society. Instead, the basic unit within the Kickapoo culture is the extended family, the Kickapoo do not speak of their family but of their 'relatives'. It looks as if each tribal member is related to everyone else in some wayi

Particularly in urban areas the households are constantly shifting according to the availability of funds and needs of kin, as Guillemin (1975) also discusses in depth for the Micmac. Community members with stable employment may be able to afford rent and deposit for an apartment or trailer. Among both the Kickapoo and the Micmac these households were almost exclusively headed by women whereas many of the co-residents were male relatives. The urban women especially want to be able to offer a home to their children even when these children only live with them temporarily. Also they often feel a need to provide an opportunity for residence to their reservation kin who come to visit the urban area, to seek employment, or who are broke. In this manner they can fulfill obligations and continue affiliations with their community. 
The pattern of frequent co-residency helps to explain the crowded housing conditions revealed by the census. Snipp (1989) found that " American Indians, in 1979 and 1980 lived in the most densely occupied housing units " (p. 107), i.e., more densely occupied than any other ethnic group. Yet these living conditions have not only economic but also cultural reasons. During my field work I stayed in several such shifting, multi-relative, single women households; it was not uncommon that six or more people would occupy a two bedroom house or apartment. The issue of cultural differences in the sense of comfort related to living density was often a topic of conversation. Usually this topic was initiated by the Kickapoo, who were particularly sensitive to these differences and expressed a preference to live with many of their kin, to socialize, to exchange information and to share household chores and financial resources and, in the process, to feel connected to the larger community. They had little comprehension for Euro-American desires for private space and isolated nuclear families.

\section{Kin Networks}

These issues point to the central role of social, and especially kin, networks among the Kickapoo and in other Indian communities. Traditional Kickapoo life focused on the community and was organized around communal subsistence or ceremonial activities. In former times, when the people lived in close proximity of villages, they worked together on one project at a time. The women, for instance, collaborated to construct an Indian home, weave cattail mats, or prepare hominy. The enactment of the Allotment Act (1887) among the Kickapoo put an end to these communal living and working conditions. Yet many elderly people still remember these days as illustrated by an 85 year old female resource person: "Women used to help each other in the village then, but the allotment cut them up, now they do it alone".

This kind of mutual aid and dependency, based on the traditional Kickapoo culture, continues to exist among them. During my field work I observed, as did Lamphere (1989) among the Navajo, that interpersonal relations were particularly close between mothers and daughters, but also with other female kin. Beside the actual residence in one household, the traditional tribal members maintain close ties to each other through a living pattern in close proximity. Today they live in neighborhood clusters within the five communities of Jones, McLouth, Choctaw, Harrah and Shawnee, visiting each other frequently. A Kickapoo's social life consists nearly exclusively of activities with other tribal members, especially those of the same generation. These relationships are often more informal than close kinship relationships. "We grew up together" is an explanation often to be heard of close social and emotional ties between two or more tribal members usually of the same gender. Because of the small size of the tribe, these friends are usually blood relatives as well.

Women explained to me that they seek out other women for companionship since they share the same interests and needs for support. These interests include concerns relating to their children or grandchildren, going to garage sales, making cattail mats, gossiping, and giving advice or sympathy in varying lifesituations. "Helping each other out" as the Kickapoo call it, is essential for the women to survive under conditions of or near poverty. As mentioned before, most women are single because of separation or work related absences of their mates. Others may be married "Indian way" and live with a male partner, who is not the father of her children and thus reluctant to share in child rearing responsibilities. Consequently, Kickapoo women depend on each other to provide child care to be able to work or to relieve personally stressful situations. These networks are also important to obtain transportation and to share information about other tribal members, health care, jobs, and other resources, for instance, opportunities to give blood in exchange for cash. The maintenance of the 'wicki-ups', the traditional Kickapoo homes which are made of cattail mats, is highly labor intensive, and therefore the cooperation of women in the construction is essential. The kin networks are also important for socializing and just enjoying each other's company. The women may visit bars together or visit each other in their homes. Sometimes Kickapoo women will work together on traditional crafts, such as basket weaving or sewing dance shawls while socializing.

Yet these social networks are also diverse. A younger woman "may help out" an older tribal member because of the high value the Kickapoo culture places on respecting elders. Such a situation is important for another reason, that is, the younger females learn tribal history, lore, and values from the elders. Among urban Kickapoo, women from other tribes, especially those with whom they had close friendship ties because they spent time together in boarding schools, were often included in these networks. Lamphere (1989) found that differences in employment among Navajo women between those who work in service and clerical jobs and those who have obtained semiprofessional or professional positions have led to a polarization along class lines that adversely effects kin networks. I did not observe such similar trends among the Kickapoo.

Because of the instability of marital relationships, the women's networks and mutual aid become even more important. Since this system is based on reciprocity, services rendered are not compensated financially. In their - economicallyy precarious situation it helps them to "get by"--since they can save money, for instance, for child care. This system gives Kickapoo women a tenuous but basic sense of material, social, and emotional security. But for most Kickapoo women these kin networks are not only the primary reference groups because they are essential for survival under poverty. More importantly, they are means to maintain their traditional culture, strengthen their cultural identity, and present a form of social organization that continues to be useful and enjoyable while allowing the women more flexibility and independence.

\section{CONCLUSION}

Biculturalism and poverty are dominant themes in the lives of many American Indian women, both consequences of involuntary incorporation into 
the US capitalist economy. Under these conditions, especially reservation communities occupy a marginal position visa vie the dominant society (Jorgensen 1978). Under these circumstances the otherwise presumed dichotomy between the private, i.e. domestic, and the public, i.e. capitalist, spheres does not exist (Albers 1983b; Ortner 1974; Sanday 1981). Because of the high rates of unemployment and underemployment wage incomes are not adequate to support many of the American Indian households. One of the consequences is that the extended family was not completely transformed into nuclear families. Kin networks often continue to provide needed resources and services as well as sustenance of the respective traditional cultures. The glimpse that the scant literature on past and contemporary American Indian women present, reveals that many aspects of traditional values, ways of life, and spirituality as well as the contemporary tribal community continue to be meaningful and of central importance to most Indian women.

The category of 'American Indian' was employed by the Federal Government to categorize a widely diverse population. In fact, even the notion of tribe as a designation for one cultural group was a label imposed by whites for the purpose of treaty negotiations (Comell 1988). Federal Indian policies such as allotment, formal education, termination, and continued threats to tribal resources and autonomy have contributed, in both the past and present, to Pan-Indian identities which exist simultaneously beside tribal, clan, and reservation identities (Nagel 1988). The census data have shown the variety of socio-economic positions and professional statuses among American Indian women, a majority of whom are struggling with poverty, biculturalism, discrimination, and symptoms of the resulting social stresses, such as substance abuse. Yet the ways in which they cope with these situations vary according to cultural tradition, available resources, and individual background and disposition.

The diversities and communalities among Indian women show their unique experiences and goals. Yet the label 'American Indian women' is not only misleading because it veils the diversity. It can also have the effect of designating them as 'other', as human beings of a different category. American Indian women have uniquely distinct cultural and historical experiences and they are, in their diverse life situations, caring for their families, trying to earn a - living, maintaining a home, and protecting their values. They are mothers and wives, often single mothers, professionals, informal teachers, and friends.

\section{ENDNOTES}

1. The differences in perception may be attributed to the different time periods or different bands that each author discusses. Powers refers to the Oglala. It is not clear which band Medicine discusses. Both describe Lakota women's roles for different time periods.
2. For a more detailed discussion of the issue see DeMallie (1983), Medicine $(1980,1983)$, Powers (1986).

3. For more detailed discussions of the historical complexities of the different periods of Indian-White relations see Comell (1988), Jorgensen (1986), Nagel (1988, 1990), Price (1972), White (1983)

4. Donna LaHarris and Iola Hayden are the directors of AIO (Americans for Indian Opportunity) and OIO (Oklahomans for Indian Opportunity) respectively.

5. While aggregate data from the 1990 census has recently become available, it has not been sufficiently disaggregated to permit the kind of analysis I have undertaken here.

6. The data of the 1980 census which deal explicitly with American Indians (United States Census of the Population. 1980. American Indians, Eskimos, and Aleuts on Identified Reservations and in the Historical Area of Oklahoma (Excluding Urbanized Areas)) are aggregated for Oklahoma according to county instead of tribal group. Therefore, no census data are available that analyze specificly the Kickapoo Tribe of Oklahoma.

\section{REFERENCES}

Aberle, David F. and Frank Flynn. 1989. "Education, Work,Gender and Residence: Black Mesa Navajo's in the 1960s."Journal of Anthropological Research. Vol. 45:4 pp.405-430.

Albers, Patricia. 1983a. "Introduction: New Perspectives on Plains Indian Women." in: Albers, P. and B. Medicine (eds.) The Hidden Half: Studies of Plains Indian Women. Lanham: University Press of America.

1983b. "Sioux Women in Transition: A Study of Their Changing Status in a Domestic and Capitalistic Sector of Production." in: Albers, P. and B. Medicine (eds.) The Hidden Half: Studies of Plains Indian Women. Lanham: University Press of America.

and Beatrice Medicine. 1983. "The Role of Sioux Women in the Production of Ceremonial Objects: The Case of the Star Quilt." in: Albers, P. and B. Medicine (eds.) The Hidden Half: Studies of Plains Indian Women. Lanham: University Press of America.

Amott, Teresa and Julie Matthaei. 1991. Race, Gender, and Work: A Multicultural Economic History of Woman in the United States. Boston: South End Press. 
Allen, Paula Gunn. 1986. The Sacred Hoop: Recovering the Feminine in American Indian Traditions. Boston: Beacon Press.

Bataille, Gretchen and Kathleen Mullen Sands.1984. American Indian Women Telling Their Lives. Lincoln: University of Nebraska Press.

Buchanan, Kimberly Moore. 1986. Apache Women Warriors. El Paso, Texas: Texas Western Press, University of Texas in El Paso.

Buffalohead, Priscilla K. 1983. "Farmers, Warriors, Traders: A Fresh Look at Ojibway Women." Minnesota History Vol 48:236-244.

Cornell, Stephen. 1988a. The Return of the Native: American Indian Political Resurgence. New York: Oxford University Press.

1988b. "The Transformations of Tribe: Organization and Self-Concept in Native American Ethnicities. Ethnic and Racial Studies. Vol 11:1. pp 27. .47 .

Deloria, Vine. 1984. "The Popularity of Being Indian: A New Trend in Contemporary American Society." Centerboard: Center for Human Relation Studies Vol.2:1.

DeMallie, Raymond. 1983. "Male and Female in Transitional Lakota Culture." in: Albers, P. and B. Medicine (eds.) The Hidden Half: Studies of Plains Indian Women. Lanham: University Press of America.

Dillingham, Betty Ann (Wilder). 1963. The Oklahoma Kickapoo. Unpublished Ph.D. Dissertation in Anthropology. Ann Harbor: University of Michigan.

Dorris, Michael A. 1981. "The Grass Still Grows, the Rivers Still Flow: Contemporary Native Americans. Daedalus. Vol. 110:2 p.43-69.

Erdrich, Louise. 1985. Love Medicine. Toronto: Bantam Books.

Eitzen, Stanley. 1988. In Conflict and Order: Understanding Society. Boston: Allyn and Bacon.

and Maxine Baca Zinn. 1989. Social Problems. Boston: Allyn and Bacon.

Etienne, Mona and Eleanor Leacock. (eds.) 1980. Women and Colonialization: Anthropological Perspectives. New York: Praeger.

Farley, John E. 1990. Sociology. Englewood Cliffs, NJ: Prentice Hall.

Friedl, Ernestine. 1975. Women and Men: An Anthropologist's View. New York: Holt Rinehardt and Winston.

Giddens, Anthony. 1991. Introduction to Sociology. New York: W.W.Norton and Company.

Grinnell, George Bird. 1972. The Cheyenne Indians: Their History and Ways of Life. 2 Vol. Lincoln: University of Nebraska Press.

Guillemin, Jeanne. 1975. Urban Renegades: A Cultural Strategy of American Indians. New York: Columbia University Press.

Harjo, Joy. 1982. She had some Horses. New York: Thunders Mouth Press.

Holder, Preston. 1974. The Hoe and the Horse on the Plains. A Cultural Development Among North American Indians. Lincoln: University of Nebraska Press.

Hungry Wolf, Beverly. 1980. The Ways of My Grandmothers. New York: William Morrow.
Inciardi, James A. and Robert A. Rothman. 1990. Sociology: Principles and Applications. San Diego: Harcourt Brace Jovanovich.

Johnson, Dirk.1991. "Census Finds Many Claiming New Identity: Indian." The New York Times National. March 5.

Jorgensen, Joseph G. 1978. "A Century of Political Economic Effects on American Indian Society, 1880-1980." The Journal of Ethnic Studies. Vol.6:3.

1986. "Federal Policies, American Indian Polities and the "New Federalism." American Indian Culture and Research Journal. Special Issue Vol.10:2. Los Angeles. American Indian Studies Center, University of Califormia.

Josephy, Alvin M. 1971. Red Power. Lincoln, University of Nebraska Press. 1982. Now that the Buffalo's Gone. New York: Knopf.

Kammeyer, Kenneth, George Ritzer, and Norman Yetman. 1990. Sociology: Experiencing Changing Societies. Boston: Allyn and Bacon.

Kehoe, Alice. 1983. "The Shackles of Tradition." in: Albers, P. and B. Medicine (eds.) The Hidden Half: Studies of Plains Indian Women. Lanham: University Press of America.

Kerbo, Harold R. 1989. Sociology: Social Structure and Social Conflict. New York: McMillan

Ketcheshawno, Vernon. 1984. "Traditional Family Systems.” Conference Proceedings of the 2nd Annual American Indian Conference on Child Abuse and Neglect., Tulsa, Oklahoma. Norman: American Indian Institute, University of Oklahoma Press.

Klein, Alan. 1983. "The Political Economy of Gender: A 19th Century Plains Indian Case Study." in: Albers, P. and B. Medicine (eds.) The Hidden Half: Studies of Plains Indian Women. Lanham: University Press of America.

Kuhlmann, Annette. forthcoming. "Conflicting Goals in Bicultural American Indian Education."

1989. Collaborative Research in Biculturalism Among the Kickapoo of Oklahoma. Unpublished Dissertation. American Studies, University of Kansas.

Lamphere, Louise. 1989. "Historical and Regional Variability in Navajo Women's Roles." Journal of Anthropological Research Vol. 45:4 pp.431456.

Landes, Ruth. 1971. The Ojibwa Woman. New York: W.W. Norton and Company.

Levy, Jerrold E., Eric B. Henderson, and Tracy J. Andrews. 1989. "The Effects of Regional Variation and Temporal Change on Matrilineal Elements of Navajo Social Organization." Journal Of Anthropological Research Vol. 45:4 pp. 351-356.

Linderman, Frank B. 1972. Pretty Shield: Medicine Woman of the Crows. Lincoln: University of Nebraska Press.

Lurie, Nancy. 1961. Mountain Wolf Woman: Sister of Crashing Thunder. Ann Arbor: University of Michigan Press. 
MacCormack, Carol P. and Marilyn Strathern (eds.). 1980. Nature, Culture, and Gender. New York: Cambridge University Press.

Martin, Calvin. 1978. Keepers of the Game: Indian Animal Relations and the Fur Trade. Berkeley: University of Califomia Press.

1987. The American Indian and the Problem of History. New York: Oxford University Press.

Matthiessen, Peter. 1983. In the Spirit of Crazy Horse. New York: Viking Press.

McElroy, Ann. 1989. "Ooleepeeka and Mina: Contrasting Responses to Modernization of Two Baffin Island Inuit Women." in: James Clifford: Being and Becoming Indian: Biographical Studies of North Americans Frontiers. Chicago: Dorsey Press.

Medicine, Beatrice. 1980. "The Interaction of Culture and Sex Roles in the Schools." Conference on the Educational and Occupational Needs of American Indian Woman. US Department of Education/ National Institute of Education. Washington, D.C.: Government Printing Office.

1983. " "Warrior Woman" - Sex Role Alternatives for Plains Indian Women." in: Albers, P. and B. Medicine (eds.) The Hidden Half: Studies of Plains Indian Women. Lanham: University Press of America.

Nagel, Joane. 1988. The Roots of Red Power: Demographic and Organizational Bases of American Indian Activism, 1950-1980. Paper presented at the annual meeting of the American Sociological Association.

1990. " Cycles of Protest and Cycles of Reform: From Termination to Self-Determination in Federal Indian Policy, 1950-1980." Paper presented at the annual meeting of the American Sociological Association.

Niethammer, Carolyn. 1977. Daughters of the Earth: The Lives and Legends of American Indian Women. New York: Collier Books.

Ortner, Sherry. 1974. "Is Woman to Nature as Man is to Culture?" in:Rosaldo, M.Z. and L. Lamphere (eds.). 1974. Woman, Culture, and Society. Stanford: Stanford University. Press.

Ortner, Sherry and Harriet Whitehead. 1984. Sexual Meanings: The Cultural Construction of Gender and Sexuality. Cambridge: Cambridge University Press.

Powers, Marla N. 1986. Oglala Women: Myth, Ritual, and Reality. Chicago: University of Chicago Press.

Price, John A. 1972. "Migration and Adaptation of American Indians to Los Angeles." in D.E.Walker (cd.) The Emergent Native Americans. Boston: Little, Brown and Company.

Reiter, Rayna R. (ed.) 1975. Towards an Anthropology of Women. New York: Monthly Review Press.

Ronda, James. 1984. Lewis and Clark Among the Indians. Lincoln: University of Nebraska Press.

Rosaldo, M.Z. and L. Lamphere (eds.). 1974. Woman, Culture, and Society. Stanford: Stanford University Press.
Sanday, Peggy. 1981. Female Power and male Dominance.: On the Origins of Sexual Inequality. Cambridge: Cambridge University Press.

Schneider, Mary Jane. 1983. "Women's Work: An Examination of Women's Roles in Plains Indian Arts and Crafts." in: Albers, P. and B. Medicine (eds.) The Hidden Half: Studies of Plains Indian Women. Lanham: University Press of America.

Schumacher, Irene. 1972. Gesellschaftsstructur und Rolle der Frau: Das Beispiel der Irokesen. Berlin: Dunker \& Humbolt; Soziologische Schriften Bd. 10.

Silko, Leslie. 1977. Ceremony. New York: Signet.

Silman, Janet. 1987. Enough is Enough: Aboriginal Women Speak Out. Toronto: The Women's Press.

Snipp, C. Matthews. 1986. "Who are American Indians? Some Observations about the Perils and Pitfalls of Data for Race and Ethnicity." Population Research and Policy Review. Vol 5:2 pp. 237-252.

1989. American Indians: The First on this Land. New York: Russell Sage Foundation.

Spector, Janet. 1983. " Male/Female Task Differentiation Among the Hidatsa." in: Albers, P. and B. Medicine (eds.) The Hidden Half: Studies of Plains Indian Women. Lanham: University Press of America.

Stuart, Paul H. 1990. "Financing Self-Determination: Federal Indian expenditures, 1975-1988. American Indian Culture and Research Journal Vol.14:2.

Szasz, Margret. 1971. Education and the American Indian: The Road to SelfDetermination, 1928 - 1973. Alberquerque: University of New Mexico Press.

Thornton, Russel. 1987. American Indian Holocaust and Survival: A Population History Since 1492. Norman: University of Oklahoma Press.

Tiffany, Sharon (ed.) 1979. Women and Society: An Anthropological Reader, Montreal: Eden Press.

Topahanso, Luci. 1982. Seasonal Woman. Santa Fe: Tooth of Time Books.

Udall, Louise. 1969. Me and Mine: The Life Story of Helen Sekaquaptewa as Told by Louise Udall. Tuscon: University of Arizona Press.

Underhill, Ruth. 1979. Papago Women. New York, Holt, Rinehart, and Winston.

United States Census of Population. 1980. Vol. 1. Characteristics of the Population. Part 1. United States Summery. Chapter C. General Social and Economic Characteristics.

American Indian, Eskimo,and Aleuts on Identified Reservations and in the Historic Areas of Oklahoma (Excluding Urbanized Areas). Tables 7, 10.

Vander Zanden, James W. 1990. The Social Experience: An Introduction to Sociology. New York: McGraw Hill.

Wallace, Richard C. and Wendy Drew Wallace. 1989. Sociology. Boston: Allyn and Bacon.

Weist, Katherine. 1983. "Beasts of Burden and Menial Slaves: Nineteenth Century Observations of Northern Plains Women." in: Albers, P. and B. 
Medicine (eds.) The Hidden Half: Studies of Plains Indian Women. Lanham: University Press of America.

Weltfish, Gene. 1965. The Lost Universe: Pawnee Life and Culture. Lincoln: University of Nebraska Press

White, Richard. 1983. The Roots of Dependency. Lincoln: University of Nebraska Press.

Whiteman, Henrietta. 1980. "Insignificance of Humanity: "Man is Tampering with the Moon and the Stars": The Employment Status of American Indian Women." Conference on the Educational and Occupational Needs of American Indian Woman. US Department of Education/ National Institute of Education. Washington, D.C.: Government Printing Office.
WOMEN'S WORK, CARE-GIVING AND TWO TRADITIONS IN SOCIAL WELFARE*

\author{
Diane Rothbard Margolis \\ The University of Connecticut
}

Mid-American Review of Sociology, 1992, Vol XVI, No. 1: 29-43

This paper analyzes differences between social welfare emanating from a reciprocity orientation that had its roots in charity and the church and social welfare emanating from a pooling orientation that had its roots in work relegated to women in the family. It suggests that pooling welfare is more appropriate to the state, but that the more successful a program is the more likely it is to blunt the public support it requires.

\section{TWO TRADITIONS IN SOCIAL WELFARE}

Alvin Gouldner noted that the norm of reciprocity "may lead individuals to establish relations only or primarily with those who can reciprocate, thus inducing neglect of the needs of those unable to do so. Clearly," he added, "the norm of reciprocity cannot apply with full force in relations with children, old people, or with those who are mentally or physically handicapped, and it is theoretically inferable that other, fundamentally different kinds of normative orientations will develop in moral codes" $(1960$, p. 178).

Children, old people and mentally or physically handicapped people usually depend for their care on women who are either unpaid workers in the home or paid workers in the home or special care-giving institutions. Social welfare programs are one means of covering the economic costs of care-giving. Though these programs have never enjoyed unanimous support, there are indications that they may presently be under greater attack than usual (Offe 1988). The purpose of this paper is to compare two normative orientatiotis toward social welfare: one that usually leads to weak programs and attacks on the welfare state and another that may be its saving moral support.

The orientation that fosters weak programs and strong opposition, is based on norms of reciprocity. Accordingly, I shall call it "reciprocity welfare." The other is based on fundamentally different normative orientations. Drawing on

* I would like to thank several anonymous reviewers for their comments on this paper and Cathy Giorgi for her research assistance. 